\title{
CANOPY HEIGHT MODELS TO MONITOR AREAS UNDER DEGRADATION IN MIXED OMBROPHILE ${ }^{1}$
}

\author{
Mauro José Alixandrini Junior ${ }^{2 *}$, Josmar Oliveira Valadares ${ }^{3}$ and Carlos Loch ${ }^{4}$
}

\footnotetext{
${ }^{1}$ Received on 05.08.2013 accepted for publication on 21.09.2016.

${ }^{2}$ Universidade Federal da Bahia, DETG, Salvador, BA - Brasil. E-mail: <mauro.alixandrini@ufba.br>.

${ }^{3}$ Universidade Federal da Bahia, MEAU, Salvador, BA - Brasil. E-mail: <josmarvaladares@hotmail.com>.

${ }^{4}$ Universidade Federal de Santa Catarina, DECV, Florianópolis, SC - Brasil. E-mail: <carlos.loch@ufsc.br>.

*Corresponding author.
}

\begin{abstract}
This research was aimed at providing a study of digital elevation models from Airborne Laser Scanner (ALS) data. The goal was to improve the forest monitoring, or more specifically, arboreal canopy monitoring, which contains the most elevated vegetation of the forest. It is also described as the surface above the canopy top. The region of rain forest between the states of São Paulo and Paraná in Brazil was analyzed. The proposed method employs the ALS system that provides information related to different vegetative cover bedding, to analyze it and reach to estimate for the most elevated stage. The methodology is based on differentiating the identified surfaces in the original set of data. It uses these surfaces with a raster, which was obtained from an interpolation of different sets of points from the surfaces of interest. The raster structure, unlike vector data, allows for processes linked to the digital processing of images. It enables implementation of digital filters over the data. The method helped in reducing the influence of errors during classification and achieving the theoretical surface. The results revealed a coherent relationship with anthropogenic influence such as the introduction of exotic vegetation. We concluded that arboreal vegetation could be an index of conservation for environmental registration and licensing organizations.
\end{abstract}

Keywords: Airborne Laser Scanner; Height of arboreal vegetation; Digital Elevations Models.

\section{MODELOS DE SUPERFÍCIES FLORESTAIS PARA O MONITORAMENTO DE ÁREAS SUJEITAS À DEGRADAÇÃO EM FLORESTAS OMBRÓFILAS MISTAS}

\begin{abstract}
RESUMO - A investigação foi conduzida para a análise da aplicação de modelos de superfície derivados de levantamentos de varredura laser aerotransportada contribuiriam para o monitoramento de florestas. O foco foi mais especificamente a análise do estrato arbóreo, que contém a parte mais elevada da vegetação de um dado tipo florestal, também descrito como superfície acima da copa dossel. É analisada uma região de Floresta ombrófila mista entre os estados de São Paulo e Paraná no Brasil. A proposta é utilizar o sistema ALS-Airborne Laser Scanner, que fornece informações ligadas a diferentes estratos da cobertura vegetal, para analisar o comportamento e alcançar uma estimativa para a altura do estrado mais elevado. A metodologia elaborada baseia-se na diferenciação de superficies identificadas no conjunto de dados originais e na utilização dessas superfícies com uma estrutura matricial "raster". Essa estrutura é obtida a partir da interpolação dos diferentes conjuntos de pontos das superficies de interesse. A estrutura matricial, ao contrário da vetorial, permite o uso de processamento digital de imagens, com isso o uso de filtros digitais sobre os dados. Estes filtros são utilizados para reduzir a influência de erros ocorridos durante a classificação e aproximar a superficie obtida da superficie teórica. Os resultados revelam um relacionamento coerente com aspectos externos de influência sobre a vegetação. Obtiveram-se estimativas que podem ser correlacionadas, por exemplo, com influências antrópicas. Assim, a altura da vegetação poderia ser um índice de conservacionismo adotado por cadastros e licenciamentos ambientais.
\end{abstract}

Palavras-chave: Sensoriamento Remoto; Sistemas de Gestão Ambiental; Modelos Digitais. 


\section{INTRODUCTION}

Arboreal canopy height has been described in the literature as an important parameter for characterizing the regeneration or degradation stage of a region. As such, it is highly relevant in studies and environmental impact reports required before engaging in activities that could be environmentally destructive.

Most studies associated with digital models focus on subtropical vegetation, such as Pfeifer et al (1999), Raumonen et al (2013), Mass et al (2008), Watt and Donoghue (2005), and Moorthy et al (2008).

In Brazil, studies such as Schaaf et al (2006) and Oliveira et al (2003) discuss the importance and special characteristics of tropical forest monitoring, particularly for Mixed and Dense Ombrophile Forests.

Dense Ombrophile Forests span the forest formations distributed on the intermediary portion of the slopes of Serra do Mar, specifically at altitudes greater than $400 \mathrm{~m}$. Regions with descending slopes and mild temperatures, influenced by the flow of cold plateau air, exhibit flora that is completely different from those at lower levels. Nonetheless, montane and submontane ecosystems are physiognomically and structurally very similar. The Montane Dense Ombrophile Forest has an average height of $20 \mathrm{~m}$.

Various species of the Lauraceae family are predominant in the upper stratum of this forest type, particularly Ocotea catharinensis, Ocotea odorifera, and Cryptocarya aschersoniana. Other species are also common, such as Copaifera trapezifolia, Aspidosperma olivaceum, Pouteria torta, and Lamanonia speciosa. Meanwhile, the lower strata are predominantly characterized by the Myrtaceae and Rubiaceae families. This formation is also characterized by the abundance of pteridophytes (ferns) present in the understory, particularly Dicksonia sellowiana and several species of the Cyatheacea family (SEMA, 2003).

This study aims to characterize the arboreal canopy height of a residual forest located in the surrounding area of the Governador Parigot de Souza Hydroelectric Power Plant in Paraná, Brazil, using data derived from Airborne Laser Scanner (ALS) and treated with image processing techniques.

\section{MATERIALS AND METHODS}

\subsection{Characteristics of the study area}

The evaluated data correspond to the area surrounding the Governador Parigot de Souza Hydroelectric Power Plant dam located on the Capivari River. The site in question is in the municipality of Campina Grande do Sul, Paraná, Brazil alongside Highway BR-116, $50 \mathrm{~km}$ north of the southern end of the portion between Curitiba and São Paulo.

ALS data was collected by LACTEC - Institute of Technology for Development, based in Paraná. This center was created by COPEL, the state energy management company of Paraná, making the electrical sector one of its main research foci.

LACTEC scans were carried out using an ATLM 2050, manufactured by the Canadian company Optech. The system has a frequency of up to $50,000 \mathrm{~Hz}$, records the first and last return pulses, has a variable scanning angle of $+/-20^{\circ}$, and can operate at a maximum nominal altitude of $2,000 \mathrm{~m}$. Table 1 shows the configurations used for data collection.

The results obtained showed an average error of $10 \mathrm{~cm}$ and a standard deviation of $50 \mathrm{~cm}$ in altitude. The larger error values were found in areas where the mesh of points generated by the topographic survey was not dense enough. During data collection, there was difficulty in determining what points corresponded to terrain in some areas, due to the large amount of litter and tripping vegetation. The ALS data present a series of constraints for their manipulation, seeing how the large volume of points presents two operating possibilities.

The first approach would consist of interpolating the data for processing in a regular grid or grayscale image. In this case, tools used in digital image processing

Table 1 - Configuration ALS.

Tabela 1 - Configurações ALS.

\begin{tabular}{lc}
\hline Parameters & Configuration \\
\hline Flight height & $2000 \mathrm{~m}$ \\
Flight speed & $280 \mathrm{~km} / \mathrm{h}$ \\
Track width & $1456 \mathrm{~m}$ \\
Scanning Angle & $40^{\circ}$ \\
Average Point Density & $1.5 \mathrm{point} / \mathrm{m}^{2}$ \\
Profiling Frequency & $30 \mathrm{kHz}$ \\
Beam Footprint & $0.54 \mathrm{~m}$ \\
\hline Source: LACTEC & \\
Fonte: LACTEC &
\end{tabular}


would be applied, since data would be aggregated in a raster grid. The downside of this approach is in the necessary interpolation and resampling, as this may heavily alter the original values.

An alternative approach is the use of coordinates as vectors, which would require changing the environment to a Computer Aid Design. In such a case, the work algorithms, necessary functions for the assortment, selection, division, and operation of the surfaces, increase in complexity. However, unlike the first method, data are not interpolated, i.e., they are less influenced, depending upon the available hardware capacity. There is an almost linear relationship between RAM and the number of processed laser points.

\subsection{Method}

Figure 1 shows the profile of a Dense Ombrophile Forest. Stratum A contains the crowns of dominant or emergent trees, which usually stand out above the continuous canopy of the forest. Just below, stratum B contains codominant trees, whose crowns touch and, as with the dominant trees, receive direct sunlight.

Eventually, stratum B might open up due to the loss of one or more trees, thereby allowing the penetration of light directly to stratum C. This stratum is composed of trees that do not typically receive sunlight otherwise, meaning that they are usually shorter. However, when a forest clearing opens, these trees quickly respond to the stimulus and tend to occupy the upper strata. These strata comprise the arboreal canopy. Under this
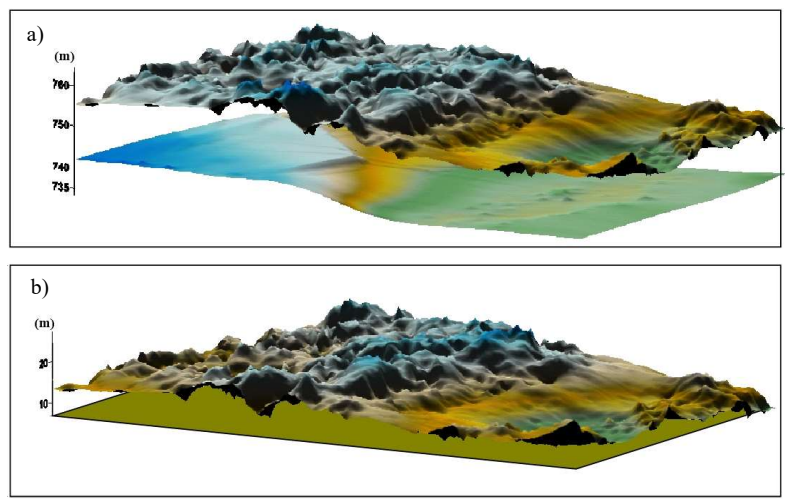

Figure 1 - a) Digital Terrain Model and Digital Surface Model and b) Vegetation Height Model.

Figura 1 - a) Modelo digital de terreno e modelo digital de superficie b) Modelo da altura da Vegetação. canopy lies vegetation that constitutes the understory - namely, stratum D, which is composed of bushes, and stratum E, an herbaceous layer composed of prostrate weeds between 30 and $70 \mathrm{~cm}$ in height (POGGIANI, 1989). Samples with different average heights were taken from both steep and flat regions within the available area.

The most common technique for obtaining the digital terrain model (DSM) of the crowns of the trees is to calculate the triangulated irregular network (TIN) of the highest reflection (with the highest point of a preset neighborhood removed) and then interpolate the points using Delaunay triangulation. Canopy models are obtained with the subtraction of the digital terrain model (DTM) from the corresponding DSM.

In order to detect points in the forest, a sufficient density of laser pulse coverage in the region is necessary. This allows for the detection of return pulses that penetrated the vegetation through the spaces left between leaves and twigs.

After the selection, individual archives were separated for each sample and, as in the original archive, ASCII features were maintained.

Samples were separated into two classes of interest:

a)Terrain Points: all points classified as terrestrial and usually derived from the last return mode.

b) Vegetation Points: all points classified as vegetation (corresponding to the canopy, plants, bushes, buildings) and usually derived from the first return mode.

In this step, data was used in its vector form. As such, vegetation and terrain points were classified based on a visual assessment of sectional points, without the use of algorithms and automated segmentation techniques.

These two classes were established in order to produce two elevation models, the first corresponding to the terrain and the second corresponding to the canopy height.

This separation of points resulted in the models shown in Figure 1a. In the following step, altimetric data for each of the models were correlated. It was not possible to do so between the surfaces without first obtaining the values corresponding to the altitude in the whole area of interest. Therefore, a regular grid model was used to compare.

Revista Árvore, Viçosa-MG, v.40, n.5, p.959-964, 2016

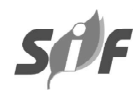


Subsequently, the subtraction of the terrain altitude from the altitude of the trees resulted in a third model corresponding to tree height, as shown in Figure 1b.

From this model, it was possible to obtain parameters such as average tree height, the number of trees of specific species, and crown volume.

\section{RESULTS}

A total of 30 equally sized rectangles, $50 \times 50$ $\mathrm{m}$ in area, were sampled in regions where the relief showed smooth and mountainous terrain, as shown in Figure 2.

The profiles were generated through the previously discussed classification of ALS points in regions of the profile line. The profiles were obtained through the vectorization of the union of those points. A large variation in altitude, directly associated with the proximity of the formation of Serra do Capivari, which is located east of the dam, can be observed.

Each sample contained between 13,000 and 30,000 ALS points derived from the archive containing the MDE, i.e., grouped points from the first and second laser pulses. From here, the areas were individually processed for the operations proposed in the methodology.

Table 2 shows the main characteristics of each area, specifically declivity, altitude, the total number of points, and total penetration of the vegetation.

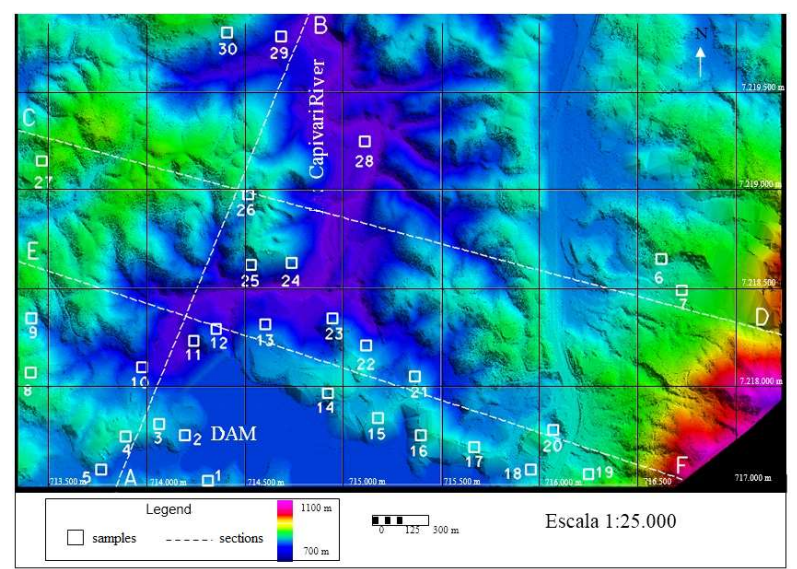

Figure 2 - Sample distribution.

Figura 2 - Distribuição das amostras.
Table 2 - Characteristics of the sampling areas. Tabela 2-Caracteristicas das areas amost

\begin{tabular}{|c|c|c|c|c|}
\hline & $\begin{array}{c}\text { Average } \\
\text { Declivity } \\
(\%)\end{array}$ & $\begin{array}{l}\text { Average } \\
\text { Altitude } \\
\text { of the } \\
\text { Sample } \\
\text { (m) }\end{array}$ & $\begin{array}{c}\text { Total } \\
\text { Points }\end{array}$ & $\begin{array}{c}\text { Vegetative } \\
\text { Penetration } \\
(\%)\end{array}$ \\
\hline Area 1 & 19 & 806 & 3273 & 24.6 \\
\hline Area 2 & 12 & 796 & 3292 & 15.8 \\
\hline Area 3 & 12 & 816 & 3253 & 26.4 \\
\hline Area 4 & 8 & 835 & 3341 & 2.9 \\
\hline Area 5 & 12 & 799 & 3103 & 2.1 \\
\hline Area 6 & 34 & 821 & 4185 & 5.4 \\
\hline Area 7 & 55 & 862 & 2985 & 2.0 \\
\hline Area 8 & 17 & 821 & 1311 & 11.1 \\
\hline Area 9 & 25 & 826 & 1466 & 4.4 \\
\hline Area 10 & 53 & 772 & 1355 & 1.1 \\
\hline Area 11 & 11 & 774 & 1708 & 7.0 \\
\hline Area 12 & 26 & 768 & 1462 & 11.3 \\
\hline Area 13 & 11 & 770 & 1373 & 8.2 \\
\hline Area 14 & 16 & 823 & 3203 & 7.7 \\
\hline Area 15 & 3 & 821 & 4440 & 25.6 \\
\hline Area 16 & 25 & 823 & 4262 & 3.1 \\
\hline Area 17 & 2 & 829 & 2886 & 23.4 \\
\hline Area 18 & 8 & 818 & 1601 & 4.6 \\
\hline Area 19 & 3 & 842 & 2600 & 4.2 \\
\hline Area 20 & 16 & 822 & 3550 & 3.3 \\
\hline Area 21 & 27 & 811 & 4195 & 2.7 \\
\hline Area 22 & 58 & 798 & 3039 & 2.4 \\
\hline Area 23 & 47 & 782 & 3255 & 3.4 \\
\hline Area 24 & 25 & 803 & 4582 & 2.1 \\
\hline Area 25 & 38 & 800 & 2287 & 3.9 \\
\hline Area 26 & 34 & 822 & 1401 & 6.2 \\
\hline Area 27 & 29 & 892 & 2838 & 4.6 \\
\hline Area 28 & 5 & 747 & 1285 & 7.6 \\
\hline Area 29 & 27 & 758 & 2777 & 2.8 \\
\hline Area 30 & 12 & 809 & 2769 & 2.5 \\
\hline
\end{tabular}

The percent declivity values correspond to the ratio between the altimetric variation of the terrain and planimetric variation. Therefore, a declivity of $100 \%$ would correspond to a $45^{\circ}$ angle between the average land surface and a horizontal surface.

\section{DISCUSSION}

The estimates correlated with different responses that could be directly associated with the regeneration of vegetation in the sampled areas. This was apparent when the responses were located in the area surrounding the reservoir.

The higher values obtained are compatible with the expected values for a Montane Mixed Ombrophile Forest. However, it is possible that the lower values 
that do not correspond indicate the insertion of an exotic species into the region. In this way, vegetation height estimation could act as strong indication of environmental change.

Associating this indicating factor with a more careful description of the testing environment can be of great value for both environmental records and environmental licensing, as it is a much more detailed survey compared to the one currently used for both cases.

This research showed one potential application of ALS, specifically in acquiring altimetric data. Such an application could highlight relationships with surrounding properties, as well as help in evaluating and monitoring areas in the hydrographic basin of the reservoir.

\section{CONCLUSIONS}

Exotic species used in traditional Brazilian silviculture, such as Pinus elliot, Pinus taeda, Eucalyptus dunni, and Eucalyptus bethami, can at least have identified. This is because the pinus and eucalyptus species, which are mostly cultivated in the south and southeast, have an adult height of up to 40 and $50 \mathrm{~m}$, respectively. This is in comparison to the average height of the Montane Mixed Ombrophile Forest, which is between 20 and $25 \mathrm{~m}$. This opens up the possibility of monitoring the migration movement of these species through the observation of exotic adults, mainly in preservation parks of the original biome. A specific evaluation of the influence of litter and tripping vegetation on the final accuracy of ALS data collection is necessary.

Automated classifications that give a better response to tropical vegetation in soil recognition for MDT derivation are needed. The major problem in this case is that most of the algorithms developed internationally are based on problems generated in temperate climates; for example, vegetation and the corresponding canopy density are typically assumed to vary by season. Testing this approach by obtaining corroborating data in homogenous regions is recommended. This will also prove useful in verifying differences in estimates for coverage on different system configurations.

The resulting reliance on winter and summer data does not accurately reflect the problems caused by various types of flora in Brazil. Applying TIN techniques to this methodology, instead of using regular grids, is also recommended. This will decrease iteration with the original data, opening up the possibility of using it for comparison, without samples, in different areas with similar vegetation.

\section{ACKNOWLEDGMENTS}

Thanks to the LACTEC team, represented by the engineer and cartographer Marlo Martins, for support and access to ALS data.

\section{REFERENCES}

MAAS, H.G.; BIENERT, A.; SCHELLER, S.; KEANE, E. Automatic forest inventory parameter determination from terrestrial laser scanner data. International Journal Remote Sensing, v.29, p.1579-1593, 2008.

MOORTHY, I.; MILLER, J.R.; HU, B.; CHEN, J.; Li, $\mathrm{Q}$. Retrieving crown leaf area index from an individual tree using ground-based lidar data.

Canadian Journal Remote Sensing v.34, p.320-332, 2008

OLIVEIRA, F.P.; FERNANDES, E.I.F.; SOARES, V.P.; SOUZA, A.L. Mapeamento de fragmentos florestais com monodominância de aroeira a partir da classificação supervisionada de imagens rapideye. Revista Árvore, v.37, n.1, p.151-161, 2013.

PFEIFER, N.; REITER, T.; BRIESE, C.; RIEGER, W. Interpolation of high quality ground models from laser scanner data in forested areas. ISPRS. November 1999

POGGIANI, F. Estrutura, funcionamento e classificação das florestas implicações ecológicas das florestas plantadas. Piracicaba: Escola Superior de Agricultura "Luiz de Queiroz", 1989.

RAUMONEN, P.; KAASALAINEN, M.; ÅKERBLOM, M.; KAASALAINEN, S.; KAARTINEN, H.; VASTARANTA, M.; HOLOPAINEN, M.; DISNEY, M.; LEWIS, P. Fast automatic precision tree models from terrestrial laser scanner data. Remote Sensing, v.5, p.491-520, 2013

SCHAAF, L.B.; FIGUEIREDO, A.F.; GALVÃO, F.; SANQUETTA, C.R. Alteração na estrutura

Revista Árvore, Viçosa-MG, v.40, n.5, p.959-964, 2016 
diamétrica de uma floresta ombrófila mista no período entre 1979 e 2000. Revista Árvore, v.30, n.2, p.283-295, 2006.

PARANÁ. Secretária Estadual do Meio Ambiente SEMA. "Atlas da vegetação do Paraná".
Curitiba: 2003.

WATT, P.J.; DONOGHUE, D.N.M. Measuring forest structure with terrestrial laser scanning. International Journal Remote Sensing, v.26, p.1437-1446, 2005. 